2. To: (Receiving Organization)

LMHC Characterization Engineering

5. Proj./Prog./Dept./Div.:

Characterization Project

8. Originator Remarks:

Supporting document submitted for review and approval prior to release.
3. From: (Originating Organization)

Characterization Engineering

6. Design Authority/Design Agent/Cog. Engr.:

GP Janicek/BL Coverdell/RN Dale
11A. Design Baseline Document? [] Yes [X] No

\section{Related EDTNO:: \\ N/A \\ 7. Purchase Order No.: \\ N/A}

9. Equip./Component No.:

N/A

10. System/BIdg,/Facility:

$200 \mathrm{G}$

12. Major Assm. Dwg. No.:

N/A

13. Pemit/Permit Application No::

N/A

14. Required Response Date:

ASAP

\begin{tabular}{|c|c|c|c|c|c|c|c|c|c|c|}
\hline \multirow{2}{*}{\begin{tabular}{|c|}
15. \\
$\begin{array}{c}\text { (A) } \\
\text { ttem } \\
\text { No. }\end{array}$ \\
\end{tabular}} & \multicolumn{6}{|c|}{ DATA TRANSMITTED } & \multirow{2}{*}{$\begin{array}{c}(\mathrm{F}) \\
\begin{array}{c}\text { Approval } \\
\text { Designator }\end{array} \\
\end{array}$} & \multirow{2}{*}{\begin{tabular}{|c|}
$(\mathrm{G})$ \\
$\begin{array}{c}\text { Rcason } \\
\text { for Trans- } \\
\text { mittal }\end{array}$ \\
\end{tabular}} & \multirow{2}{*}{$\begin{array}{c}\text { (H) } \\
\text { Origi- } \\
\text { nator } \\
\text { Dispo- } \\
\text { sition }\end{array}$} & \multirow{2}{*}{$\begin{array}{c}\text { (I) } \\
\begin{array}{c}\text { Receiver } \\
\text { Dispo- } \\
\text { sition }\end{array}\end{array}$} \\
\hline & \multicolumn{2}{|c|}{ (B) Document/Drswing No. } & $\begin{array}{l}\text { (C) } \\
\text { Sheet } \\
\text { No. }\end{array}$ & $\begin{array}{l}\text { (D) } \\
\text { Rev. } \\
\text { No. }\end{array}$ & \multicolumn{2}{|c|}{ (B) Title or Description of Data Transmitled } & & & & \\
\hline 1 & \multicolumn{2}{|c|}{ HNF-3700 } & N/A & 0 & \multicolumn{2}{|c|}{$\begin{array}{l}\text { RISER EQUIPMENT } \\
\text { DECONTAMNATION } \\
\text { ENGINEERING TASK PLAN }\end{array}$} & 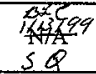 & 1 & 1 & \\
\hline & & & & & & & & & & \\
\hline & & & & & & & & & & \\
\hline & $\cdot$ & & & & & & & & . & \\
\hline .......... & $\begin{array}{llll} & \ldots \\
\ldots\end{array}$ & $(+\ldots \ldots \ldots$ & …….... & $\ldots \ldots \ldots \ldots$ & .. & $\cdots \quad \cdots$ & & $\cdots$ & $\ldots \ldots$ & $=$ \\
\hline & KEY & 25: & $\therefore \therefore$ & $2: a^{2}$ & $\therefore \therefore$ & & & & & \\
\hline & roval Designator $(R)$ & & Reason $\mathrm{f}$ & or.Transmittal & & $\ldots$ & ... Dispositio & on $(H) \&(\boldsymbol{l})$ & $\ldots \ldots \ldots$ & $\cdots \cdots$ \\
\hline $\begin{array}{l}\mathrm{E,S}, \mathrm{Q} \\
(\mathrm{sec} W \mathrm{l}\end{array}$ & $\begin{array}{l}\text { Dor N/A } \\
\text { (C-CM-3-S, Sec. 127) }\end{array}$ & $\begin{array}{l}\text { 1. Approval } \\
\text { 2. Release } \\
\text { 3. Information }\end{array}$ & $\begin{array}{l}\text { 4. Revie } \\
\text { 5. Post-I } \\
\text { 6. Dist. }\end{array}$ & Receipt Ackno & w. Required) & $\begin{array}{l}\text { 1. Approved } \\
\text { 2. Approved w/com } \\
\text { 3. Disapproved w/co }\end{array}$ & & $\begin{array}{l}\text { 4. Revicwed } \\
\text { 5. Revicwed } \\
\text { 6. Receipt ac }\end{array}$ & $\begin{array}{l}\text { o/comment } \\
\text { o/comment } \\
\text { nowledged }\end{array}$ & \\
\hline
\end{tabular}

17. SIGNATURE/DISTRIBUTION

(See Approval Designator for required signatures)

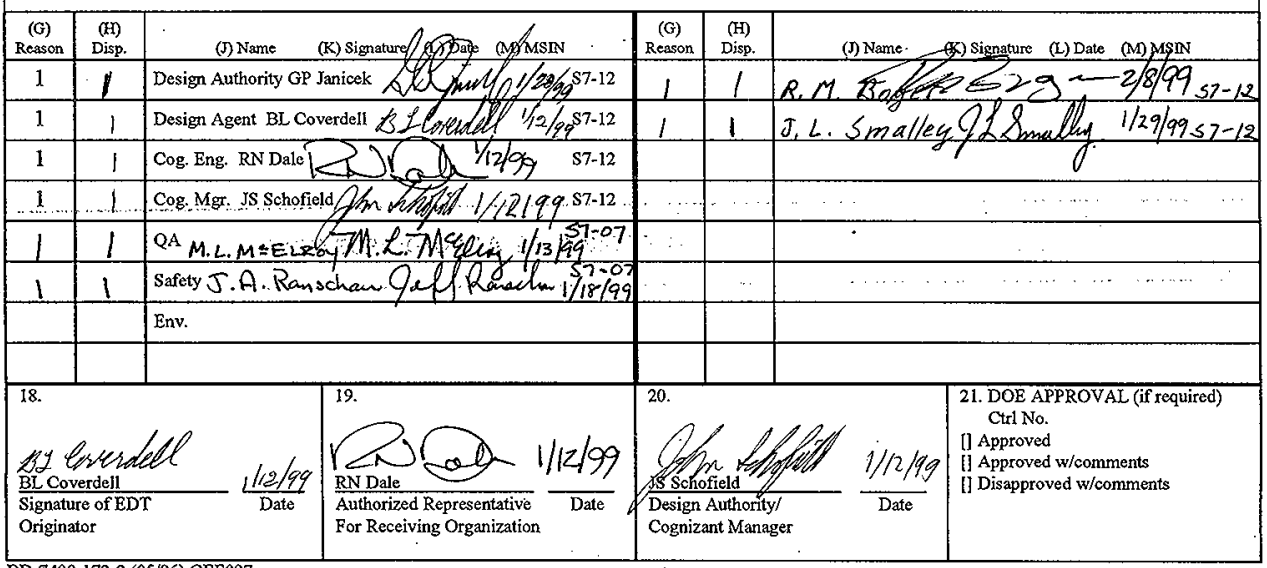


HNF-3700, Rev. 0

\title{
RISER EQUIPMENT DECONTAMINATION ENGINEERING TASK PLAN
}

\author{
R.M. Boger \\ Prepared by Lockheed Martin Hanford Company \\ Richland, WA 99352 \\ U.S. Department of Energy Contract DE-AC06-96RL13200
}

$\begin{array}{lll}\text { EDT/ECN: } 620265 & \text { UC: } 2070 & \\ \text { Org Code: } 74900 & \text { Charge Code: CACN: } 102613 & \text { COA: EI00 } \\ \text { B\&R Code: EW3120074 } & \text { Total Pages: } 10\end{array}$

Key Words: Characterization Project, Sampling, Riser, Riser Equipment, Decontamination

Abstract: This Engineering Task Plan ensures that LMHC 1998a, Corrective Action \#7 is completely addressed by Characterization Engineering. The deliverable is an Engineering Study that evaluates decontamination of riser equipment components and considers additional engineered features to reduce potential exposure to workers operating the riser equipment.

TRADEMARK DISCLAIMER. Reference herein to any specific commercial product, process, or service by trade name, trademark, manufacturer, or otherwise, does not necessarily constitute or imply its endorsement, recommendation, or favoring by the United States Government or any agency thereof or its contractors or subcontractors.

Printed in the United States of America. To obtain copies of this document, contact: Document Control Services, P.O. Box 950 , Mailstop H6-08, Richland WA 99352, Phone (509) 372-2420; Fax (509) 376-4989.
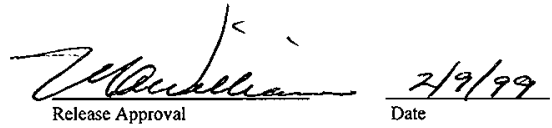

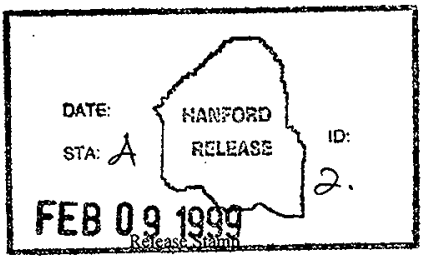

Approved for Public Release 
HNF-3700, Rev. 0

\section{RISER EQUIPMENT DECONTAMINATION ENGINEERING TASK PLAN}

Prepared for Lockheed Martin Hanford Corporation Characterization Engineering Group

By

B. L. Coverdell

COGEMA Engineering Corporation

February 1999 


\section{TABLE OF CONTENTS}

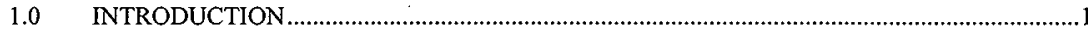

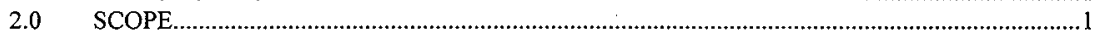

3.0 DESCRIPTION

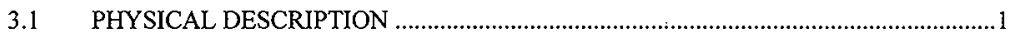

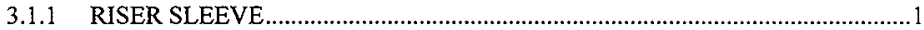

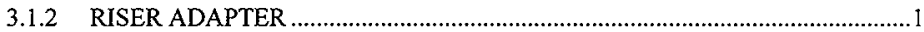

3.1.3 DRILL ROD WASHER MANIFOLD …......................................................

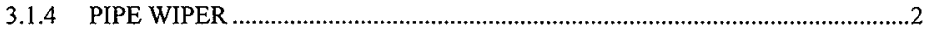

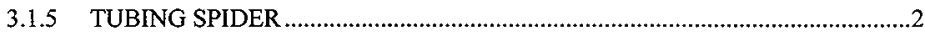

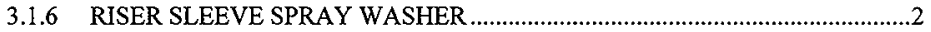

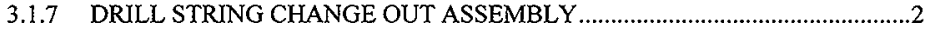

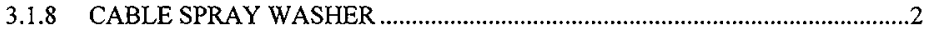

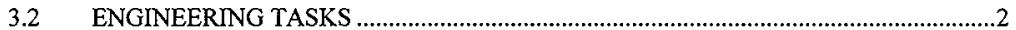

3.2.1 Additional Equipment that Provides Containment ...............................................

3.2.2 Decontamination of Riser Equipment and Components ........................................

3.2.3 Additional Engineered Features/Components ........................................................

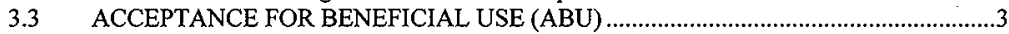

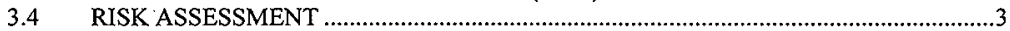

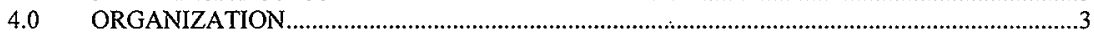

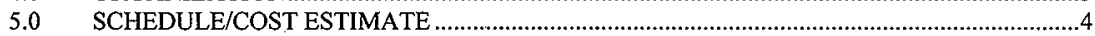

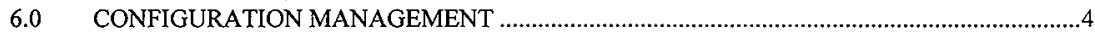

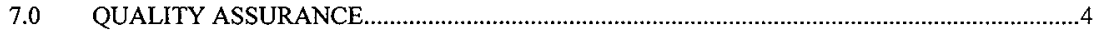

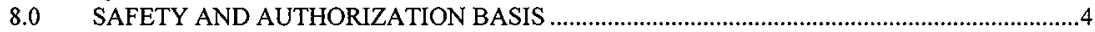

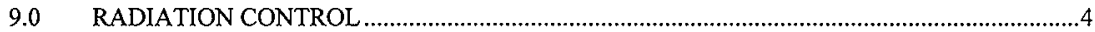

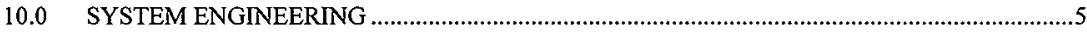

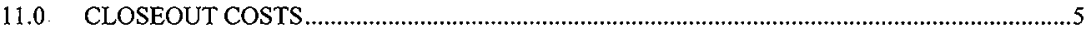

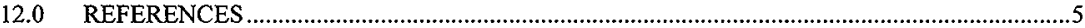

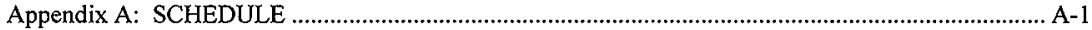




\subsection{INTRODUCTION}

On October 15, 1998, two Characterization Project Operations (CPO) employees were found to have contaminated clothing. An operator had 300,000-dpm/100 $\mathrm{cm} 2$ beta/gamma, no alpha, contamination on his coat sleeve and a Radiation Control Technician (RCT) had $10,000 \mathrm{dpm} / 100 \mathrm{~cm} 2 \mathrm{beta} / \mathrm{gamma}$, no alpha, on his shirt sleeve.

The CPO swing shift crew was working in TX tank farm, performing sampling activities at 241-TX-113. TX tank farm is a "clean farm" and does not require anti-contamination clothing for entry. The CPO personnel were dressed in normal work clothes. An operator and an RCT were performing a pre-job survey that involved removing bagging around the riser equipment. When the RCT saw that the contamination readings from smear samples of the riser equipment were greater than expected, the job was suspended. Crewmembers were then directed to areas of lower background radiation for personnel surveys. During personnel surveys, reportable contamination was found on the coat sleeve of the operator who had been involved in the pre-job survey and on the shirtsleeve of the RCT who had been involved in the pre-job survey. No other personnel were found to be contaminated.

Because of this off normal event Characterization Engineering was given the following corrective action: Examine the process methodology used for core sampling operations to determine practicality and potential long-term advantages of reducing personnel contact with contaminated equipment.

\subsection{SCOPE}

This Engineering Task Plan ensures that LMHC 1998a, Corrective Action \#7 is completely addressed by Characterization Engineering. The deliverable is an Engineering Study that evaluates decontamination of riser equipment components and considers additional engineered features to reduce potential exposure to workers operating the riser equipment. This engineering study shall also address any released design features that have failed to be implemented.

\subsection{DESCRIPTION}

\subsection{PHYSICAL DESCRIPTION}

A typical riser arrangement consists of the following equipment, the components are listed in order as attached from the riser up; riser sleeve, riser adapter, drill rod washer manifold, pipe wiper (donut) and tubing spider (foot clamp).

\subsubsection{RISER SLEEVE}

The lack of lateral support on the drill string when sampling in some waste tanks reduces the allowable down force due to buckling. The riser sleeve is used to provide additional lateral support and, thus, increase the allowable down force. See drawing H-2-690128.

\subsubsection{RISER ADAPTER}

The riser adapter allows the listed riser equipment to be attached to various riser sizes. The risers used for core sampling are either 4", 6", 8", 12" and 16" in diameter. See 
drawing $\mathrm{H}-2-690132$.

\subsubsection{DRILL ROD WASHER MANIFOLD}

When the drill string is removed from a riser some of the tank waste will stick to the exterior surfaces. To reduce worker exposure to high levels of radiation the drill string is spray washed with a Bromide solution at 500 psi. The drill rod washer manifold allows spray washing of the drill string as it is removed from a waste tank. See drawing H-291671.

\subsubsection{PIPE WIPER}

The pipe wiper is shaped like a donut. The exterior of the drill string is wiped clean of debris when it is pulled through the center of the pipe wiper. See drawings H-2-690134 and $\mathrm{H}-2-821457$.

\subsubsection{TUBING SPIDER}

The tubing spider or foot clamp provides positive position locking of the drill string. This done to allow sections of the drill string to be added or removed. See drawings H-2690134 and $\mathrm{H}-2-821457$.

\subsubsection{RISER SLEEVE SPRAY WASHER}

During core sampling operations, radioactive tank waste may become attached to the interior surfaces of the rise sleeve. The riser sleeve spray washer is used to remove the waste from the surface riser sleeve and flush it back into the tank. See drawing H-2690131.

\subsubsection{DRUL STRING CHANGE OUT ASSEMBLY}

Core Sample Trucks \#2,3 and 4 have the capability of using Nitrogen as a purge gas to prevent the buildup of flammable gases. The drill string change out assembly is used to keep purge gas pressure in the drill string while adding or removing drill string. See drawing $\mathrm{H}-2-690133$.

\subsubsection{CABLE SPRAY WASHER}

During core sampling operations the grapple hoist cable or sampler hoist cable can become coated with radioactive tank waste. The cable spray washer uses high pressure water to remove the tank waste. See drawing $\mathrm{H}-2-81842$.

\subsection{ENGINEERING TASKS}

This Engineering Task Plan requires the completion of an Engineering Study that addresses the following: 
HNF-3700, Rev. 0

\subsubsection{Additional Equipment that Provides Containment}

The Engineering Study shall identify and examine any new equipment that may provide additional containment and prevent the spread of contamination.

\subsubsection{Decontamination of Riser Equipment and Components}

The Engineering Study shall address how the riser equipment and components are decontaminated. The study shall identify all decontamination methods that are currently in use. It shall also identify any new decontaminating methods that may be used. Each method shall be evaluated to determine the feasibility of the method.

\subsubsection{Additional Engineered Features/Components}

This Engineering Study shall address the addition of engineered features/components to reduce the potential for radiation contamination to workers operating the riser equipment. Each method shall be evaluated to determine the feasibility of the engineered feature/components.

\subsection{ACCEPTANCE FOR BENEFICIAL USE (ABU)}

The tasks specified by this Engineering Task Plan makes no modifications, therefore, an Acceptance for Beneficial Use form is not required.

\subsection{RISK ASSESSMENT}

There is no risk associated with completing this task, however, there may be risk associated with not completing this task. That risk would be the continued potential exposure of workers to contaminated equipment.

\subsection{ORGANIZATION}

\section{COGNIZANT ORGANIZATIONS}

Characterization Engineering

Manager - R. M. Boger

Project Manager - J. L. Smalley

Design Authority - G. P. Janicek

Performing Personnel - TBD

Characterization Field Engineering

Cognizant Manager - J. S. Schofield

Cognizant Engineer - R. N. Dale

\section{SUPPORTING ORGANIZATIONS}

Characterization Project Operations Maintenance 
Supervisor - B. J. Shoemake

Characterization Project Ops Truck Sampling

Supervisor - J. S. Lee

Characterization Project Quality Assurance

Manager - S. M. Byers

TWRS Safety Services

Manager - M. T. Hughey

Radiation Control

Manager-T. A. Shoemaker

\subsection{SCHEDULE/COST ESTIMATE}

\section{SCHEDULE}

The target completion date for this task is June 15, 1999. Appendix A contains the schedule of activities for this task.

\section{$\underline{\cos T}$}

Labor costs due to Characterization Engineering is estimated at the following:

- Prepare Report

- Review and Approve Report

- Incorporate Comments and Issue Report

Total
200 man hours.

80 man hours.

25 man hours.

305 man hours.

\subsection{CONFIGURATION MANAGEMENT}

The Engineering Study shall be released as a supporting document per HNF-PRO-439 (FDH 1997).

\subsection{QUALITY ASSURANCE}

Quality Assurance will be responsible for review and approval of the Engineering Study.

\subsection{SAFETY AND AUTHORIZATION BASIS}

Safety will be responsible for review and approval of the Engineering Study.

\subsection{RADIATION CONTROL}

Radiation Control (RadCon) will be responsible for review and approval of the Engineering Study. 


\subsection{SYSTEM ENGINEERING}

This activity is necessary to support the characterization of the waste in the underground waste tanks on the Hanford site. This activity supports the Tank Farms task identified in the Work Breakdown Structure (WBS) as task 1.1.1.1.1.3.1.3, Core Sampling Systems (LMHC 1998b)

\subsection{CLOSEOUT COSTS}

No closeout costs are associated with this task.

\subsection{REFERENCES}

Drawings, Hanford Document Control,

H-2-91671 Sheet 1-3, Drill Rod Washer Manifold Assembly and Details,

H-2-690128 Sheet 1-2, Riser Sleeve Assembly,

H-2-69013 I Sheet 1-2, Riser Sleeve Spray Wash Assembly,

H-2-690132 Sheet 1, Riser Adapter Assembly,

H-2-690133 Sheet 1-2, Sampler Change Out Assembly RMCST

H-2-690134 Sheet 1-5, Drill String Arrangement RMCST,

H-2-821457 Sheet 1-6, Drill String Arrangements Truck \#2,

Hanford Site, Richland, Washington.

FDH 1997, HNF-PRO-439, Supporting Document Requirements, Fluor Daniel Hanford, Inc., Richland, Washington.

LMHC 1998a, Occurance Report, RL-PHMC-TANKFARM-1998-0128, Lockheed Martin Hanford Company, Richland, Washington.

LMHC 1998b, HNF-SP-1230, Rev. 1, Tank Waste Remediation System Waste Characterization Fiscal Year 1999 Multi-Year Work Plan WBS 1.1, Lockheed Martin Hanford Corporation, Richland, Washington. 
HNF-3700, Rev. 0

Appendix A: SCHEDULE

Page A-1 


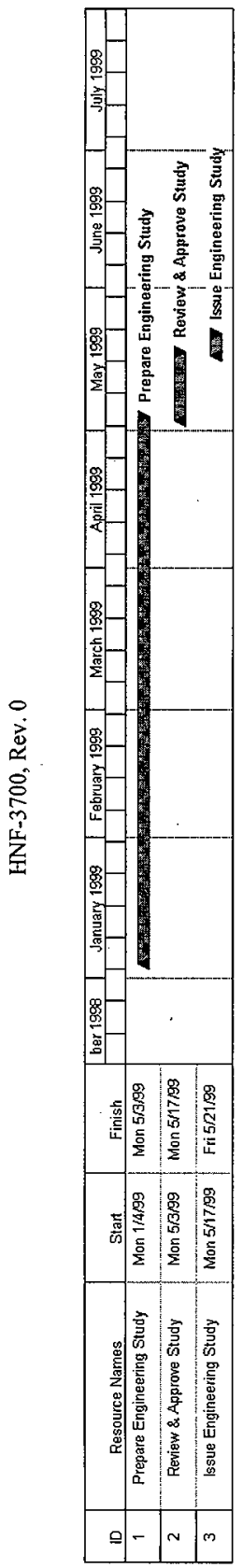

产 